\title{
A survey of the mechanical properties of concrete for structural purposes prepared on construction sites
}

\section{Um estudo das propriedades mecânicas do concreto para fins estruturais preparado em canteiros de obras}

R. R. J. RIBEIRO rosane_ribeiro25@hotmail.com

H. J. F. DIÓGENES ' hidelbrando@ct.ufpb.br

M. V. NÓBREGA c marcilenenobrega@ufersa.edu.br

A. L. H. C. EL DEBS d analucia@sc.usp.br

\begin{abstract}
This paper aims to study the concrete dosage conditions for structural purposes in construction sitesl, and the impacts of non-compliance of structural concrete for structural safety, having as study case the city of Angicos / RN. Were analyzed the dynamic elasticity modulus, static elasticity modulus and the compressive strength of concrete samples. Was conducted to collect the survey data, a field research aiming to gather information about dosage of concrete used in the works, as well as the collection of cylindrical specimens of $150 \mathrm{~mm}$ diameter by $300 \mathrm{~mm}$ of height, prepared according to practice of those professionals. The study indicated a clear necessity to reflection on the subject, since there is no concern, or even, a lack of knowledge by the interviewed professionals regarding the care and procedures necessary for the production of concrete with satisfactory quality, once at least $50 \%$ of evaluated construction sites presented compressive strength lower than $20 \mathrm{MPa}$, minimal strength to structural concrete, as recommended by ABNT-NBR 6118:2014.
\end{abstract}

Keywords: concrete, mechanical properties, technological control, construction site.

\section{Resumo}

O presente trabalho tem como objetivo estudar as condições de dosagem do concreto para fins estruturais, produzido em canteiros obras, assim como avaliar a influência do controle tecnológico nas propriedades mecânicas do concreto e os impactos da não conformidade do concreto estrutural para a segurança estrutural, tomando como estudo de caso a cidade de Angicos/RN. Para tal foram analisadas propriedades como: módulo de elasticidade dinâmico, módulo de elasticidade estático e resistência à compressão. Foi realizado, para coleta dos dados, pesquisa de campo com intuito de coletar informações sobre a execução do concreto empregado nas obras, assim como a moldagem de corpos de prova cilíndricos de $150 \mathrm{~mm}$ de diâmetro por $300 \mathrm{~mm}$ de altura, obtidos de misturas dosadas conforme a prática dos profissionais ali presentes. $\mathrm{O}$ estudo indicou a evidente necessidade de reflexão sobre o tema exposto, visto que não há preocupação, ou ainda, falta conhecimento por parte dos profissionais em relação aos cuidados e procedimentos necessários para produção de concretos com qualidade satisfatória, dado que, pelo menos, $50 \%$ das obras avaliadas apresentaram resistências à compressão inferiores a $20 \mathrm{MPa}$, resistência mínima para concretos estruturais, conforme preconiza a ABNT-NBR 6118:2014.

Palavras-chave: concreto, propriedades mecânicas, controle tecnológico, canteiro de obra. 


\section{Introduction}

The large use of concrete as a construction material brings many concerns to the involved professional regarding its quality. The usual way to ensure the satisfactory behavior of used concrete is to control some chosen properties of the material, such as elasticity modulus, compressive strength and workability, aiming to achieve the structural performance and safety requirements imposed by the Standard Codes. However, many factors can interfere on the properties of the materials and consequently on the quality of the obtained concrete, since the behavior is directly associated to the used materials, the chosen admixture and the production process. First step to ensure the concrete intended characteristics producing a desired performance is the correct chose of the components besides their correct storage avoiding any contamination. Subsequent step is the design of the concrete dosage defining the ideal proportion of each component [14].

NBR 12655: 2006 [5] determines the procedures for mix, control and reception of concretes made with Portland cement, stablishing two of dosage method: empirical or rational and experimental. First method permits defining the dosage empirically for concrete of class $\mathrm{C} 10$, with minimum cement consumption of $300 \mathrm{~kg} / \mathrm{m}^{3}$. Regarding rational and experimental dosage, the procedure is developed using materials and conditions similar to the construction site for concretes from class $\mathrm{C} 15$ or higher. The dosage is defined based on the design requirements and implementation conditions, and must be redone each time a change occurs regarding brand, type or class of cement, origin and quality of aggregates and additional components.

Besides determining conditions for the preparation of concrete admixture and concrete reception, NBR 12655: 2006 [5] also stablishes the responsibilities of the involved professionals and gives the acceptance criteria for both types of the concrete, prepared onsite and in production centers. Those criteria are related to slump tests and compressive strength tests or other tests if necessary, so that it is checked the level of concrete satisfaction regarding performance and durability of the structure facing the exposure conditions.

Large constructions usually have monitoring of concrete, including all aspects of production, from the choice of the materials to the curing process and formwork stripping. Small and medium-sized constructions, however, most of the times neglect the normative specifications for the technological control of concrete, with the connivance of those responsible for this control [12].

In a survey conducted in 2008 on the procedures used in the production of concrete in the South Central region of Sergipe for small and medium-sized constructions, Gomes Neto et al. [12] reported quite negative results. Although it was not expected that constructions in the interior of the state presented control similar to large works located in the capital, it was expected that there were at least some basic technological care. Since the construction sites had professionals responsible by the works, it was expected controlling on the amount of mixing water and on the concrete compressive strength at 28 days.

Matta et al. [15] in a survey entitled: "Comparative study of the technical and financial performance of the concrete prepared in the plant and work," also detected a great influence of human performance on the concrete characteristics, particularly if there is not a good control during concrete preparation.

\subsection{Objectives}

Thus, the present work aims to study the production conditions of concrete used for structural purposes. Small and medium-sized construction sites are focused evaluating the influence of technological control on the mechanical properties of concrete. Based on the available technical literature, a discussion on the impacts of non-compliance of structural concrete for structural safety is also presented. It is also an objective to alert the community installed in the vicinity of the Federal Rural University of Semi-Arid Campus Angicos (UFERSA - Angicos), about the risks associated to poor technological management of concrete

Therefore, to achieve the considered objectives, it is proposed the experimental evaluation of the dynamic modulus of elasticity, the static modulus of elasticity and the compressive strength of concrete from some construction sites, as well as the discussion and dissemination of the obtained results.

\section{Materials and experimental program}

The experimental program presented in the following items of this study are the results of a research conducted by the student Rosane Rayanne Jota Ribeiro as the Final Project of the Civil Engineering course, in the Rural Federal University of Semi-Arid, Campus Angicos. She was also a voluntary member of a Research Project named Acoustic Response: An alternative to the technological control of concrete, mortar and pottery for Angicos and Region, where the basis of this study were acquired.

\subsection{Field of study}

The studied sites are located in the city of Angicos / RN, in the Potiguar Central Hinterland, with an area of $741.65 \mathrm{~km} 2$ and an estimated population of 11,549 inhabitants [13]. The research was conducted in the period comprising the months of April to July, 2014.

\subsection{Considered construction sites}

Ten sites were selected, among residential, commercial and public buildings. These were cataloged and then a form to obtain the necessary information for the study was applied. The issues addressed in the form were:

i. Who owns the building?

ii. Which are the construction purpose and the delivery time?

iii. The construction has a technical lead? If so, how he conducts the building control?

iv. What is the purpose (s) and feature (s) of the concrete used in the site?

v. Who and how was determined the used admixture(s)?

vi. Is there some technological control of concrete?

vii. The concrete is produced in the site?

viii. What type of binder, sand and gravel are used in the concrete production? In which deposit were acquired sand and gravel?

ix. The concrete mix is manual or mechanical? How is made the mix of concrete components?

$x$. How is the storage of the component materials of concrete (binder, sand, crushed stone and water)?

xi. Which are the dimensions of the stretchers of sand and gravel? 


\section{Figure $1-a)$ Test for obtaining the longitudinal dynamic modulus, b) Test for obtaining the dynamic flexural modulus}

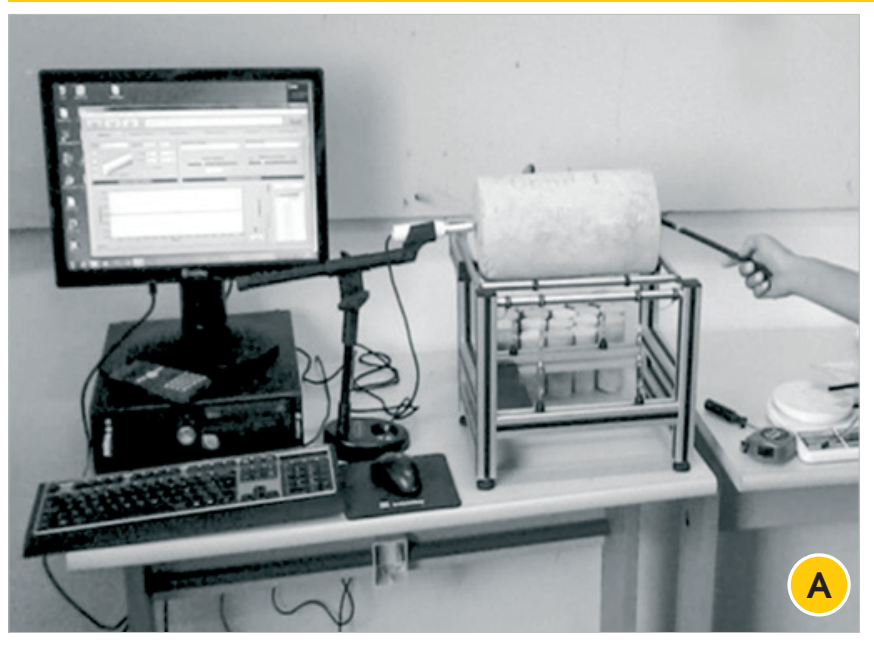

xii. Have concrete ever presented some anomaly? If so, what kind of anomaly?

\subsection{Procedures for samples collection}

They were collected six (6) cylindrical specimens with dimensions 150 $\mathrm{mm}$ diameter by $300 \mathrm{~mm}$ in height, for each evaluated project, 60 specimens, in total. The collection took place according to the NBR 5738: 2008 [1], always being held by the same person.

\subsection{Slump test}

In each site participant of the research, the consistency of concrete was investigated through the test popularly known as Slump Test. The procedures for testing were performed according to NBR NM 67: 1998 [6]

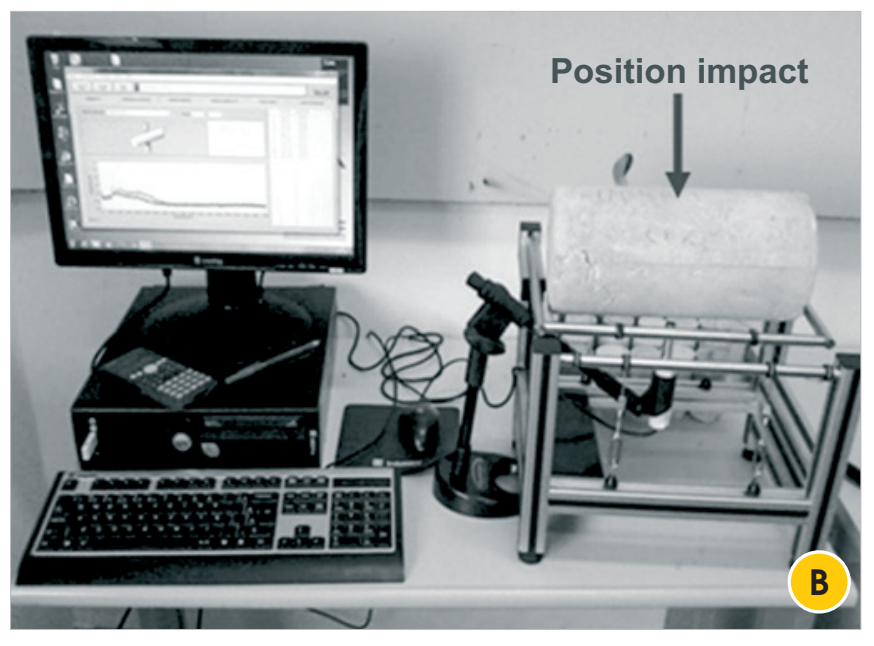

\subsection{Dynamic elasticity modulus}

Six (6) specimens for each assessed site were tested using the Sonelastic $₫$ software. The Sonelastic $₫$ determines the elastic moduli and damping from the natural vibration frequencies obtained by the impulse excitation technique. This test was performed according to the recommendations of ASTM C215: 2008 [7].

In the impulse excitation technique, the acoustic response in a defined direction of vibration is obtained when the concrete specimen is connected to wires at nodal points and receives a flick that induces vibration. This response consists of one or more natural vibration frequencies, from which is computed the modulus of elasticity [10]. Figure [1] shows the execution of the test.

It is noteworthy that this test was preferably chosen for the availability of the equipment in the campus of UFERSA - Angicos, which is

Table 1 - Construction sites with technical support

\begin{tabular}{|c|c|c|}
\hline $\begin{array}{l}\text { Construction sites } \\
\text { (CS) }\end{array}$ & Type of building & Monitoring of responsible technician \\
\hline 1 & Professors Block 02 UFERSA - Angicos & Daily \\
\hline 2 & $\begin{array}{c}\text { Laboratory of Civil Engineering - } \\
\text { UFERSA/Angicos }\end{array}$ & Daily \\
\hline 3 & Cafeteria UFERSA - Angicos & Daily \\
\hline 4 & Restaurant and inn & Twice a week \\
\hline 5 & Commerce and house & There is not \\
\hline 6 & House & There is not \\
\hline 7 & Bakery & Twice a week \\
\hline 8 & University residence of UFERSA - Angicos & Daily \\
\hline 9 & House & Monthly \\
\hline 10 & Municipal health center & Twice a week \\
\hline
\end{tabular}


still under construction. It was acquired through a research grant from CNPq (Process No. 409952 / 2013-3), because the relatively low cost when compared to conventional equipment.

\subsection{Static elasticity modulus}

After performing the non-destructive testing to determine the dynamic modulus of elasticity, three (3) specimens of the batch of six (6) collected in each site, were transported to the Building Materials Laboratory of the Federal University of Rio Grande do Norte (UFRN), where the process of capping with sulfur and subsequent completion of the static modulus of elasticity and compressive strength tests were performed. The remaining specimens were preserved, since there is an interest of using them in future research on aspects of durability.

The tests performed to determine the concrete static modulus of elasticity were performed according to the NBR 8522: 2008 [3]. Two (2) specimens out of three (3) were separated for this purpose and one (1) of them was used to estimate the concrete initial compressive strength, avoiding any damage to the strain gauge due to a sudden rupture of the specimen.

\subsection{Compressive strength}

The compressive strength of concrete was determined by axial compression tests of cylindrical specimens, according to the requirements set by the NBR 5739: 2007 [2]. In this test thirty (30) specimens, three (3) of each construction site, were subjected to axial compression in servo-hydraulic press EMIC DL-30000 with $300 \mathrm{KN}$ load capacity.

\section{Results and discussion}

\subsection{Forms application}

The 10 construction sites included in the research showed great diversity of functions, ranging from university cafeteria and laboratory facilities to single-family residence, as shown in Table [1]. This diversity is the result of increasing development for which the city has undergone since 2009 , when it became a federal university center.

The constructions that before were limited to few residences and commercial establishments now have another purpose, in order to meet the needs for infrastructure of the new university and Angicos community.

This fact produced a new culture in construction processes in the region, starting with the deployment of a technician responsible for monitoring the sites. Although this does not occur in all cases and not every day, an increasing trend of this practice is observed in the town. This is likely when it is observed that there is a new pole generator of skilled labor in the city.

This fact influenced a new culture in construction processes, starting with the deployment of a technician responsible for monitoring the work. Although this practice does not occur in all cases, not every day, you can see a breakthrough in this direction and an increasing trend of implementation of this practice. This trend is likely when it is observed that there is a hand pole generator of skilled labor in the city.

Analyzing the national panorama, according to estimative of the Federal Council of Engineering and Agronomy (Confea) [8], Brazil has a deficit. of 20,000 engineers per year In this sense, access to these professionals in remote locations from large urban centers, it is difficult and often expensive (or almost inaccessible).

When comparing, for example, the income per capita of the town of Angicos / RN, R \$334.85, with the income of the state capital, Natal / RN, R \$ 921.29, according to DATASUS [13] it can be noticed that this is a determining factor for the access to expert technical service. In table [1] it can be observed that the monitoring of a technical manager varies with the size and character of the construction. For public buildings 1, 2, 3 and 8, considered larger compared to the others, the

\section{Table 2 - Concrete proportions adopted and applicability of concrete}

\begin{tabular}{|c|c|c|c|c|}
\hline Construction site & $\begin{array}{l}\text { Proportion } 1: \mathbf{a}^{1}: \mathbf{b}^{1}: \\
\quad \mathbf{a} / \mathbf{c}^{2} \text { (in mass) }\end{array}$ & $\begin{array}{l}\text { Who determines the } \\
\text { concrete mix }\end{array}$ & $\begin{array}{l}\text { Method used to } \\
\text { determine the } \\
\text { proportion }\end{array}$ & $\begin{array}{l}\text { Applicability } \\
\text { of concrete }\end{array}$ \\
\hline 1 & $1: 2,80: 4,40: 0,56$ & Contractor & Does not know & $\begin{array}{l}\text { Foundation, pilar } \\
\text { and beam }\end{array}$ \\
\hline 2 & $1: 2,90: 3,64: 0,56$ & Contractor & Does not know & $\begin{array}{l}\text { Foundation, pilar } \\
\text { and beam }\end{array}$ \\
\hline 3 & $1: 2,73: 5,24: 0,61$ & Engineer & Spreadsheet & $\begin{array}{l}\text { Foundation, pilar } \\
\text { and beam }\end{array}$ \\
\hline 4 & $1: 2,17: 2,37: 0,56$ & Engineer & Does not know & $\begin{array}{l}\text { Foundation, pilar, } \\
\text { beam and slabs }\end{array}$ \\
\hline 5 & $1: 4,35: 4,75: 1,08$ & Mason & Experience & Pillar, beam and slabs \\
\hline 6 & $1: 4,35: 4,75: 1,44$ & Hodman and Mason & Experience & Pillar and beam \\
\hline 7 & $1: 4,35: 4,75: 0,80$ & Engineer & Does not know & $\begin{array}{l}\text { Foundation, pilar } \\
\text { and beam }\end{array}$ \\
\hline 8 & $1: 3,92: 4,28: 0,72$ & Master builder & Experience & Footing \\
\hline 9 & $1: 4,35: 1,58: 1,08$ & Engineer & Does not know & Pillar and beam \\
\hline 10 & $1: 4,35: 2,37: 1$ & Engineer & Does not know & Pilar \\
\hline
\end{tabular}


daily presence of a qualified professional has been verified, as in commercial buildings 4 and 7 . A similar situation is observed for the municipal health center building, construction 10 , with monitoring only two days a week. However, for buildings 5 and 6 , considered smaller, there is no professional monitoring and mason himself is "responsible" for the construction.

As can be seen in Table [2], although there is no technical support solely for buildings 5 and 6 , just the concrete used for buildings $1,2,3$ and 4 did not exceed the maximum limit of 0.65 for the water / cement ratio, as set in NBR 6118: 2014 [4]. It is noted that for building 6, the used water / cement ratio was about $122 \%$ greater than the limit established by the standard code. The used admixtures were distinct in all situations; however, for constructions 5, 6 and 7 the only differential parameter is the used water /cement ratio.

Table [2] also shows that in three buildings the admixtures were defined by: mason (work 5), stonemason and servant (work 6) and work master (work 8), based on experience only. However, it should be noted that this last construction held a responsible technician on a daily basis. In the building 3 , unlike those, the responsible engineer determined the dosage of concrete making use of a spreadsheet. In the other cases the dosages were determined by an engineer, however, people who answered the form did not inform the methodology used for the determination of the admixtures.

It should be noted that the persons who provided the information were representatives of companies / persons hired to perform the constructions, however, in some cases these representatives were "temporary responsible" (stockmen, trainees, bricklayers, etc.). They lead the works in the absence of a superior authority, since not always there was a responsible engineer. Purposely, filling out the form was not restricted to engineers or owners in order to assess as the design indeed happened.

It is a consensus that the most reliable way to establish a mix is using the scientific methods already established in the literature. It is determined based on material properties, target compressive strength and desired workability of concrete. At the end, its adequacy should be verified by testing, to verify if the target concrete characteristics were met.

The aggregates used for the production of concrete usually were not stored in accordance with the recommendations of ISO 12655: 2006

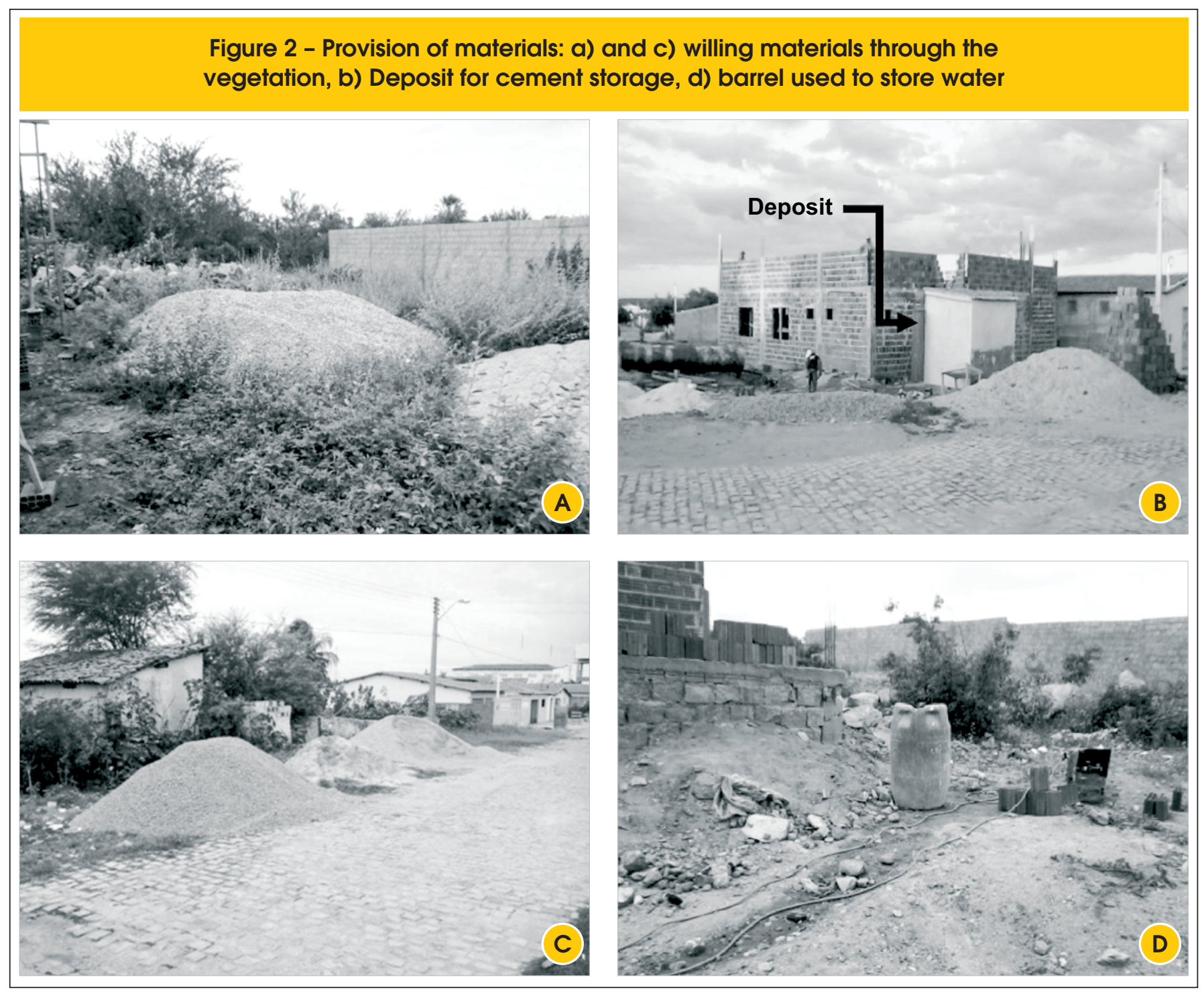




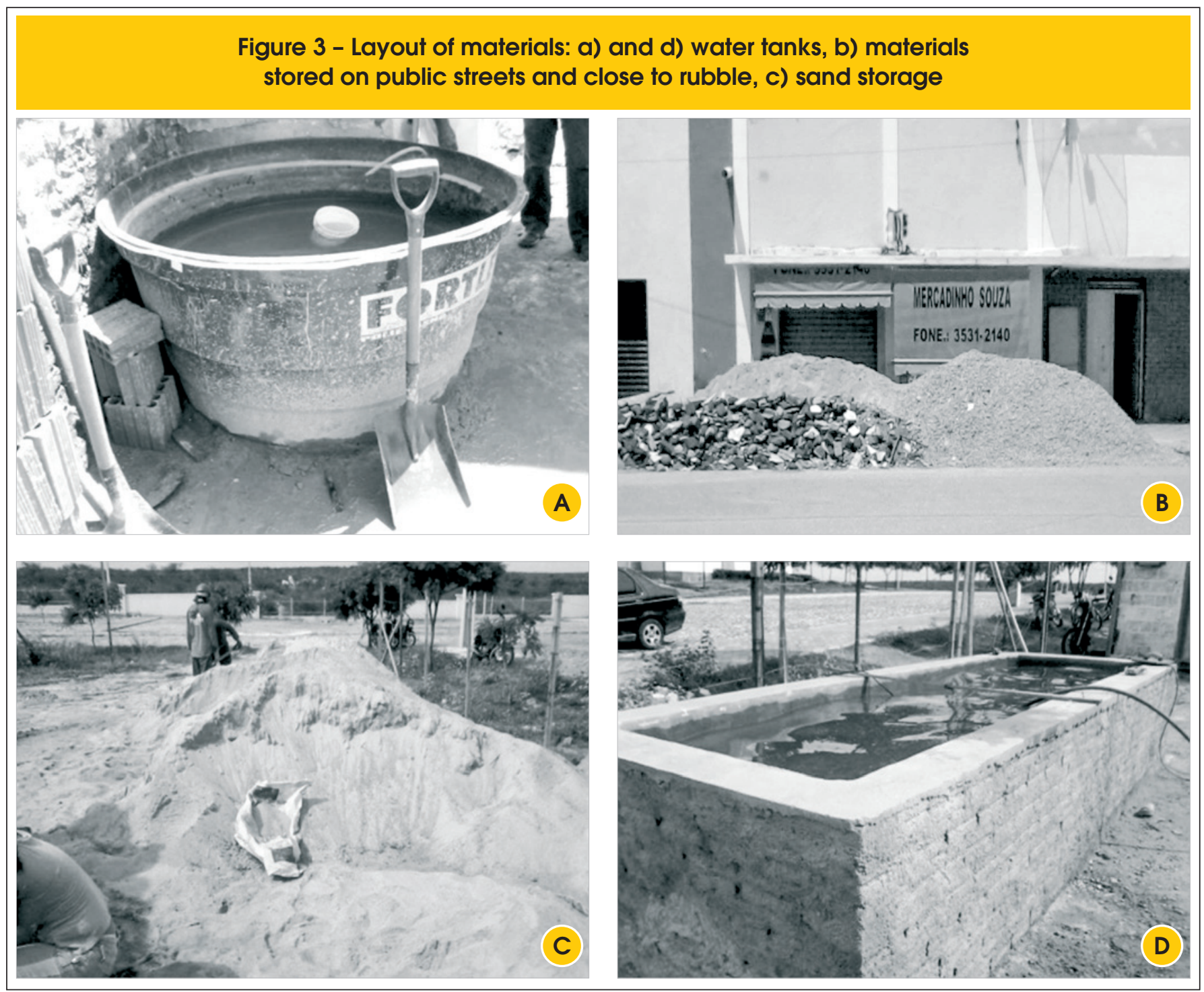

[5], being vulnerable to contamination, as shown in Figures [2] and [3]. Generally, the cement was placed in deposits in the sites or in the neighborhood.

The predominantly used sand was coarse and medium sized, while the coarse aggregate consisted of crushed granite numbers 0,1 and 2. The measuring of the granular materials was made using wheelbarrows, stretchers or even tins. For the water, the used instrument was a not graduated bucket, with the exception of the construction 9 where the addition of water occurred with a hose. So it is clear the complete lack of control over the amount of water added to the mixture. For homogenization of concrete they were used both, manual and mechanical processes. Table [3] describes the materials and tools used for the production of concrete.

When asked if the concrete had shown any irregularities, all the managers immediately said no. However, Figure [4] shows that $10 \%$, or only one construction (3), had performed the technological control of concrete till then, which implies that in the other cases the actual mechanical properties of the used concrete were not really known.

\subsection{Slump test}

The first analyzed property was the consistency of the concrete (Figure [5]). It was observed that $50 \%$ of the buildings preferred a "slightly dry" concrete, and the lower rebate, of $35 \mathrm{~mm}$, reported for the sites 1,2 and 4 . The remaining ones opted for a more plastic consistency, seeking greater workability, thus requiring a larger amount of water, since additive was not used in any site.

Despite the sites 5 and 6 had the same proportions of aggregates and little difference of consistency they presented a considerable variation in the used amount of water. Furthermore, as will be shown below, the compressive strength of test specimens from site 7 was 33\% lower than that from site 6 , which also had the same amount of dry materials. It should be noted that on several occasions it has been observed that the measure bucket was not completely filled during the addition of water, which turned even more inaccurate the information regarding the volume of used water.

The construction 7 showed the highest rebate followed by the construction 10, however, the latter used additional 10 liters of water and 
Table 3 - Materials and tools used for the production of concrete

\begin{tabular}{|c|c|c|c|c|c|}
\hline Construction site & Sand & $\begin{array}{l}\text { Granitic } \\
\text { crushed rock }\end{array}$ & Cement type & $\begin{array}{l}\text { Homogenization } \\
\text { of concrete }\end{array}$ & $\begin{array}{l}\text { Tools for prepare } \\
\text { the proportions }\end{array}$ \\
\hline 1 & Coarse sand & $N^{0} 1$ & CP IV-32 RS & Mechanics & $\begin{array}{c}\text { Padiola and } \\
\text { bucket }\end{array}$ \\
\hline 2 & Coarse sand & $N^{0} 1$ & CP IV-32 RS & Mechanics & $\begin{array}{c}\text { Padiola and } \\
\text { bucket }\end{array}$ \\
\hline 3 & Medium sand & $N^{0} 1$ & CP IV-32 RS & Mechanics & $\begin{array}{c}\text { Padiola and } \\
\text { bucket }\end{array}$ \\
\hline 4 & Coarse sand & $N^{0} 1$ & CP \|I Z-32 RS & Mechanics & bucket \\
\hline 5 & Medium sand & $N^{0} 1$ & CP IV-32 RS & Manual & $\begin{array}{l}\text { Wheelbarrow } \\
\text { and bucket }\end{array}$ \\
\hline 6 & Coarse sand & $\mathrm{N}^{\circ} \mathrm{O}$ & CP IV-32 RS & Manual & $\begin{array}{l}\text { Wheelbarrow } \\
\text { and bucket }\end{array}$ \\
\hline 7 & Coarse sand & $N^{0} 1$ & CP IV-32 RS & Mechanics & $\begin{array}{l}\text { Wheelbarrow } \\
\text { and bucket }\end{array}$ \\
\hline 8 & Medium sand & $N^{0} 1$ & CP II -32 RS & Mechanics & $\begin{array}{l}\text { Wheelbarrow } \\
\text { and bucket }\end{array}$ \\
\hline 9 & Coarse sand & $\mathrm{N}^{\circ} 0$ & CP \| Z -32 RS & Manual & $\begin{array}{l}\text { Wheelbarrow } \\
\text { and bucket }\end{array}$ \\
\hline 10 & Coarse sand & $N^{\circ} 2$ & CP II -32 RS & Manual & $\begin{array}{l}\text { Wheelbarrow } \\
\text { and bucket }\end{array}$ \\
\hline
\end{tabular}

smaller proportion of coarse aggregate. In view of the opposed data, it is believed that the amount of water used in the construction 7 was much higher than that reported.

\subsection{Módulo de elasticidade dinâmico}

Figure [6] presents the average results for the dynamic elastic modulus. As expected, the longitudinal dynamic moduli were higher than the flexural moduli since the concrete has a higher rigidity to compression than flexure.

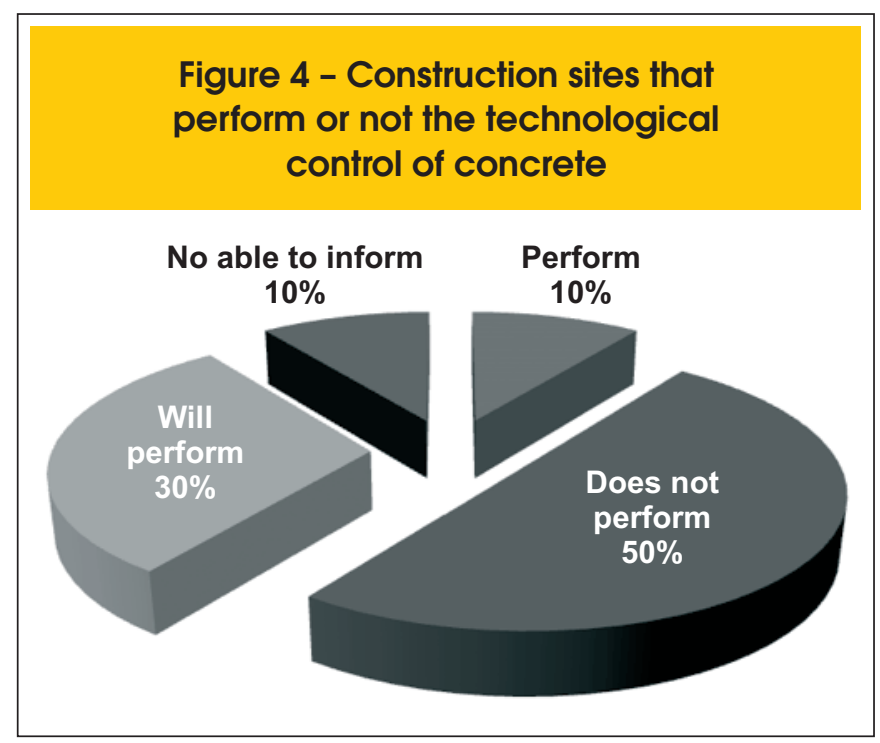

The concrete from constructions 7,9 and 10 are those with smaller moduli, while the constructions 2, 4, 6 and 8 present the higher values. The higher the water / cement ratio of the concrete, the lower the obtained modulus of elasticity. Sites 6 and 9 , which have adopted the same types of aggregates and similar dosages, differing only the proportion of gravel and water, obtained values of dynamic modulus of elasticity with a difference over 4.7 GPa.

Dynamic modules of higher values possibly will lead to higher

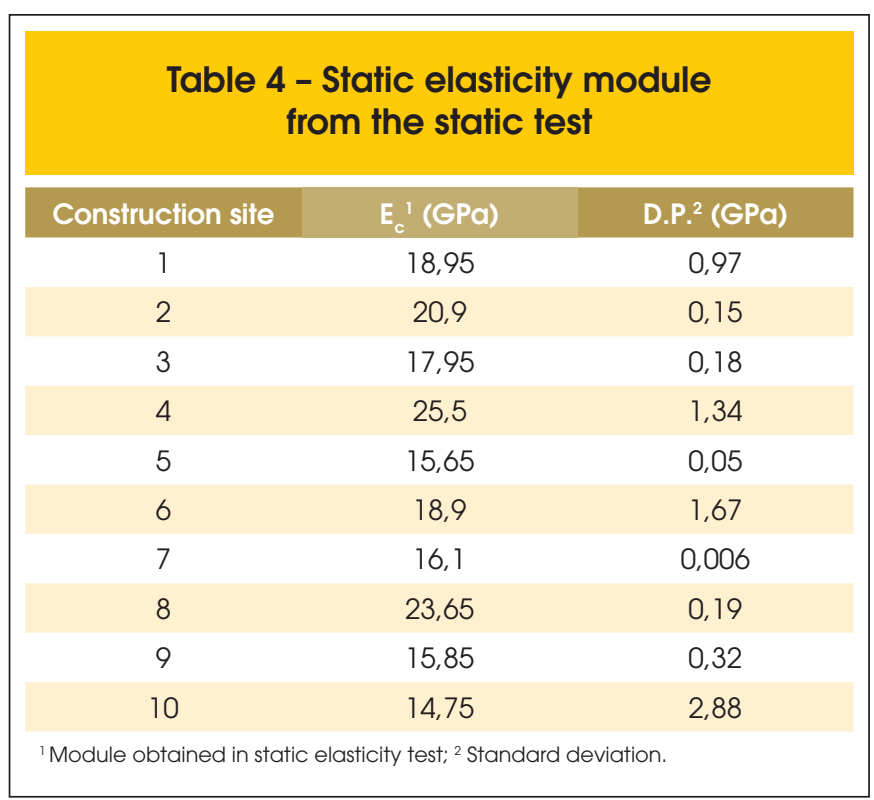


Figure 5 - Slump of concrete and water volume

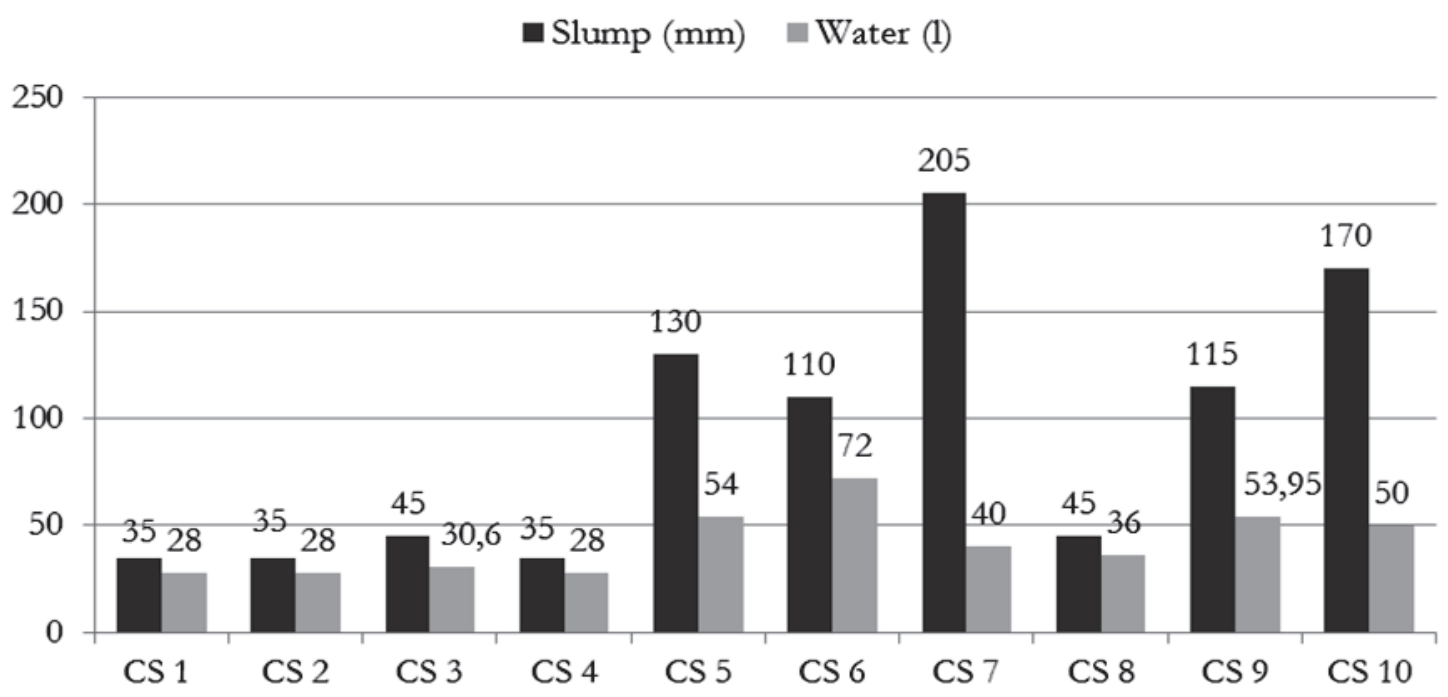

static modules, and consequently to concrete with higher compressive strength and lower flow.

\subsection{Static elasticity modulus}

Table [4] presents the average results obtained for the static elasticity modulus. Among the 10 construction sites, only 2, 4, 8 had a value for the static modulus higher than $20 \mathrm{GPa}$. NBR 6118: 2014 [4] states that the elastic deformation of the concrete depends on the concrete mix and nature of the aggregates. This is evidenced by the results of Table [4], since the constructions which had the lowest static modules (works 10, 5, 9, 7, 3, 6, 1, respectively) used admixtures with the highest water / cement and aggregates ratios.

Adopting larger aggregates proportion will produce concretes with

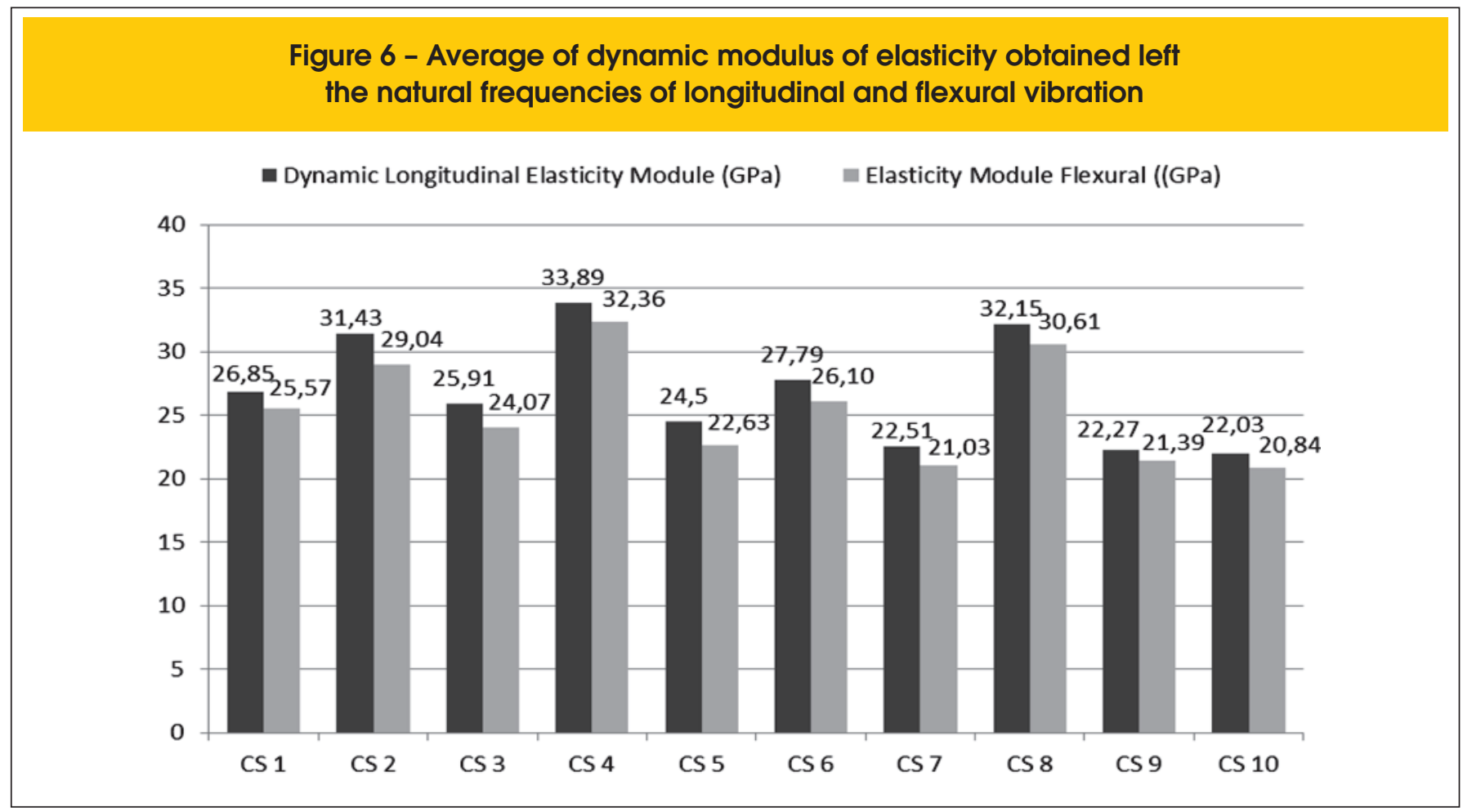




\begin{tabular}{|c|c|c|}
\hline \multicolumn{3}{|c|}{$\begin{array}{l}\text { Table } 5 \text { - Difference between the } \\
\text { longitudinal dynamic modulus and the } \\
\text { static modulus of elasticity }\end{array}$} \\
\hline \multirow{2}{*}{ Construction site } & \multicolumn{2}{|c|}{ Difference } \\
\hline & $\%$ & $(G P a)$ \\
\hline 1 & 29,4 & 7,90 \\
\hline 2 & 33,5 & 10,53 \\
\hline 3 & 30,7 & 7,96 \\
\hline 4 & 24,8 & 8,39 \\
\hline 5 & 36,1 & 8,85 \\
\hline 6 & 32,0 & 8,89 \\
\hline 7 & 28,5 & 6,41 \\
\hline 8 & 26,4 & 8,50 \\
\hline 9 & 28,8 & 6,42 \\
\hline 10 & 33,0 & 7,28 \\
\hline
\end{tabular}

drier consistency, requiring additional water to get workability, which will result in a decrease of the elasticity modulus.

The dynamic modulus corresponds approximately to the initial tangent modulus, in general 20,30 and $40 \%$ higher than the static modulus of elasticity for concretes with high, medium and low strength, respectively [14]. However, the authors do not indicate which static modulus such deformation is associated to. For comparison, Table [5] presents the difference between the dynamic modulus of elasticity originating from the longitudinal vibration frequencies and the static modulus. As it can be seen, the values are similar to those suggested in the literature.

\subsection{Compressive strength}

Compressive strength values obtained in the tests described in item

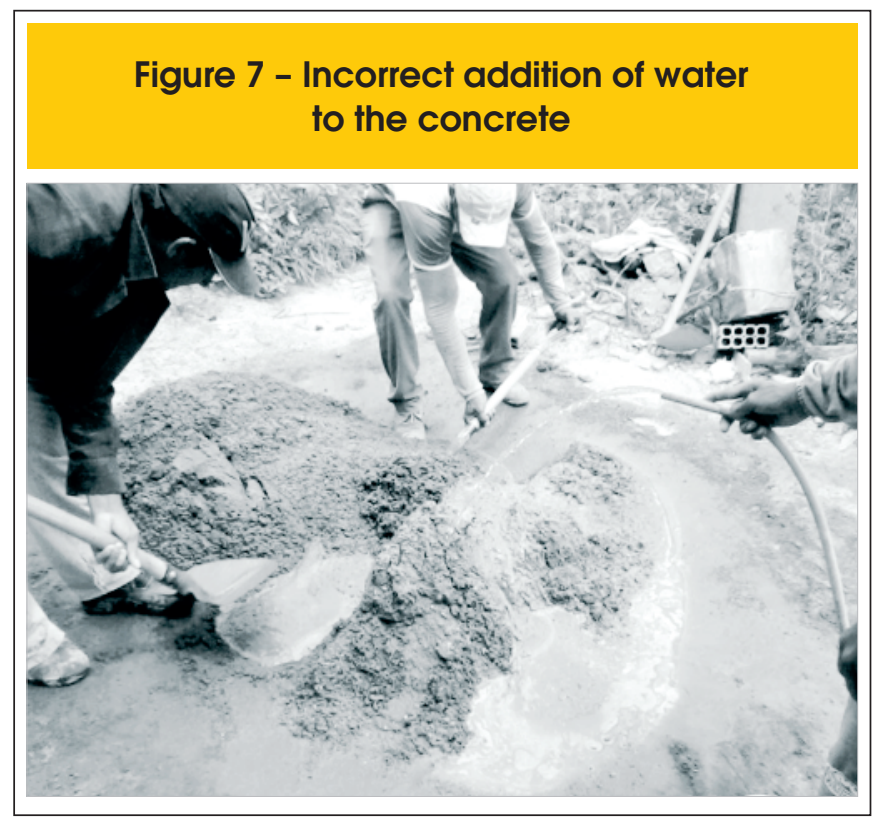

2.7 are presented in Table [6]. The results ranged from $14.48 \mathrm{MPa}$ (site 10) to $44.48 \mathrm{MPa}$ (site 4).

Note that the concretes with higher compressive strength were those concerning the medium sized constructions, whose dynamic modulus reached higher values. However, the same cannot be said for the small sized constructions.

Construction sites 4, 2, 8, 6:01 respectively, had the highest compressive strength values, while the others even reached the minimum value of 20 MPa required in NBR 6118: 2014 [4]. Conveniently, sites with satisfactory concrete compressive strength are those that have daily or weekly monitoring of a technician, except for site 6 .

Analyzing the water / cement ratio (a / c) as one of the influential parameters on the quality of the concrete, it is clear that the constructions with concrete lower compressive strength (works 5, 7, 9 and 10) used a higher proportion of water. In the site 9 , the $\mathrm{w} / \mathrm{c}$ ratio

\section{Table 6 - Strength of concrete in compression}

\begin{tabular}{|c|c|c|c|c|}
\hline Construction site & $\begin{array}{l}\text { Compression strength } \\
\text { (MPa) }\end{array}$ & Standard deviation & $\mathrm{Ed}^{*}(\mathrm{GPa})$ & $a / c$ \\
\hline 1 & 23,46 & 5,45 & 26,85 & 0,56 \\
\hline 2 & 29,32 & 0,47 & 31,43 & 0,56 \\
\hline 3 & 19,44 & 5,08 & 25,91 & 0,61 \\
\hline 4 & 44,48 & 0,94 & 33,89 & 0,56 \\
\hline 5 & 17,42 & 0,83 & 23,83 & 1,08 \\
\hline 6 & 24,76 & 2,63 & 27,79 & 1,44 \\
\hline 7 & 18,6 & 0,16 & 22,51 & 0,80 \\
\hline 8 & 25,31 & 1,50 & 32,15 & 0,72 \\
\hline 9 & 16,45 & 1,33 & 22,27 & 1,08 \\
\hline 10 & 14,48 & 1,66 & 22,03 & 1 \\
\hline
\end{tabular}


seems to be much higher than reported, since at certain times there was no control of the amount of water added to the mixture, as seen in Figure [7].

For construction 6 , despite the higher $\mathrm{w} / \mathrm{c}$ ratio informed, a very significant concrete compressive strength was obtained. It is noteworthy that one of the study's premises was the non-interference of the researchers on the mixing / dosage procedures. So, an increase in the amount of cement may possibly have happened, producing a change in the adopted mix not reported by the respondent.

\subsection{A brief discuss on the costs of the absence of concrete technological control}

As noticed in previous sections, it was observed a significant absence of technological control of concretes in most of the researched construction sites. In this sense, within the objectives set out in item 1.1, this study aims to alert the community from the university for the problems associated to the non-compliance of the concrete used in the constructions. For this, two main axes of discussion had been established:

\section{About structural safety}

It is known that non-compliance of the concrete can cause various problems, mainly of structural nature, since the compressive strength and elasticity modulus are key parameters for the structural design establishing the construction safety.

Santiago [17] in his study of the non-conform concrete produced in Brazil and its influence on structural reliability reports that, among the structural elements, the short columns subjected to axial compression are the most dependent on the compressive strength of concrete. The author [17] also reported a significant reduction in the reliability of short columns due to the non-conformity of concrete.

The reduction in the reliability of the structures or structural elements generated by the low compressive strength is something that needs to be addressed immediately by the technician. It is imperative to avoid physical and psychological risks to the people around the construction sites or even after, during the service life of the buildings. The non-compliance of concretes can directly affect the structural safety of the buildings.

Cunha et al. [9], in their work on structural accidents, discussed the causes of the collapse of a four (4) floors building in Volta Redonda / $\mathrm{RJ}$ that caused the death of eight (8) people and left 24 (twenty four) injured. Among the reasons that led to the fall of the building was detected the low compressive strength of concrete, possibly due the use of incorrect admixture, lack of vibration and inadequate curing of concrete. This fact confirms once again the need for greater concern, control and supervision over the use of nonconforming concrete.

\section{Economic impact on the constructions}

If, in one hand, the use of non-conform concretes can reduce the safety of the structures causing accidents, on the other this can lead to serious financial losses. According to Magalhães [16], the noncompliance of concretes results in significant economic losses, as they may need project reassessment, extraction and testing of samples, strengthening and even demolition of the structure. The greater the need for concretes with higher resistance, the greater will also be the cost to repair the problems due to non-compliance of concrete. In this regard, using as reference the full cost table provided by the Secretary of Infrastructure of Ceara (SEINFRA), a cubic meter of concrete with compressive strength $20 \mathrm{MPa}$ costs $\mathrm{R} \$ 302.52$, while concretes $\mathrm{C} 25$ and $\mathrm{C} 30$ cost $\mathrm{R} \$ 309.11$ and $\mathrm{R} \$ 332.98$, respectively [18]. But the grout, widely used in structural strengthening, necessary most of the times that the non-compliance of concrete is presented, costs $R \$ 4,105.99 / \mathrm{m} 3$, including the costs of casting and curing [18]. Note also that most of the constructions evaluated in this study were carried out with public funds, where the non-compliance of concretes should not occur, under penalty of repaying the monetary losses to the public treasury.

Therefore, a precise analysis on the factors and processes that lead to the non-compliance of concretes in many civil constructions is the first step to correct this problem. Achieving the specified standards appears to be an important issue to be discussed by the civil construction industry, since the damages outweigh the costs of preventive actions.

\section{Conclusion}

This study evaluated the conditions of production and dosage of concrete for structural purposes produced at construction sites. An experimental analysis of some parameters for fresh and hardened concrete, as consistency, modulus of elasticity and compressive strength was performed, which allowed the authors inferring the quality of the used structural concrete.

Based on the obtained results, it was verified the relevance of the presence of a technician supervising the construction. In Angicos / $\mathrm{RN}$, where this study was focused, there was a clear improvement in the properties of concretes produced on sites with professional supervision. However, in some cases, adopted admixtures were not sufficient to guarantee the minimum conditions of safety and durability specified by the standard codes.

The results showed that in $70 \%$ of the studied sites the static elasticity modulus showed values lower than $20 \mathrm{GPa}$. Table 8.1 from ABNT NBR 6118: 2014 [4] presents $25 \mathrm{GPa}$ as the minimum value for the modulus of elasticity and the equivalent compressive strength of $20 \mathrm{MPa}$. In this sense, only $10 \%$ of the assessed constructions would meet this standard, considering, of course, the target for compressive strength as $20 \mathrm{MPa}$. It can also be observed that the relationship between the dynamic and static modulus is similar to the values suggested in the references [14].

Regarding the compressive strength of concrete, in $50 \%$ of the constructions presented values below $20 \mathrm{MPa}$. It is worth noting that only the constructions $1,2,3,4$ and 8 had a compressive strength specified in the design, whereas the others had no structural design at all. Still, the constructions 1 and 3 did not meet the $25 \mathrm{MPa}$ designed strength, while the others met the minimum specified strength, in the case of constructions 2 and 8 of $25 \mathrm{MPa}$, and for the constructions 4 of $30 \mathrm{MPa}$. It is important to note that some of the buildings were public and had federal management, and theoretically should go through strict quality control.

In general, it was observed that the concrete mixes practiced in the sites often do not satisfy the required workability and mechanical properties. There are mixes with excess or insufficient sand, gravel and / or water, characterizing the absence of effective dosage methods.

The lack of quality of used materials as well as their inadequate 
storage can affect the outcome of the samples. In addition, the absence of correction of the humidity for aggregates may have caused water / cement ratio higher than intended. The lack of knowledge of the professionals involved in the production process also contributed significantly to changes in the quality of the obtained concrete.

Thus, there is a clear need for public awareness on the issues addressed in this study; not only for the Potiguar Central Hinterland, where this study was conducted, but in a broader way. Concrete is widely used as construction material, with little or none monitoring of its properties in most of the small constructions. And yet, this awareness must reach especially the technical community that has ignored a priori the risks for structural safety and durability of the buildings by not following the regulatory requirements.

\section{Acknowledgements}

The authors would like to thank CNPq (Nacional Council of Research and Development), by the support to the project "Acoustics Response: An alternative to the technological control of concrete, mortar and pottery for Angicos and Region.", and to the Laboratory of Materials and Construction of UFRN for carrying out the tests.

\subsection{References}

[1] ASSOCIAÇÃO BRASILEIRA DE NORMAS TÉCNICAS. Moldagem e cura de corpos-de-prova cilíndricos ou prismáticos de concreto: NBR 5738. Rio de Janeiro, 2008.

[2] ASSOCIAÇÃO BRASILEIRA DE NORMAS TÉCNICAS. Concreto - Ensaio de compressão de corpos-de-prova: NBR 5739. Rio de Janeiro, 2007.

[3] ASSOCIAÇÃO BRASILEIRA DE NORMAS TÉCNICAS Concreto - Determinação dos módulos estáticos de elasticidade de deformação e da curva tensão-formação: NBR 8522 . Rio de Janeiro, 2008.

[4] ASSOCIAÇÃO BRASILEIRA DE NORMAS TÉCNICAS. Projeto de estruturas de concreto armado: NBR 6118. Rio de Janeiro, 2014.

[5] ASSOCIAÇÃO BRASILEIRA DE NORMAS TÉCNICAS. Concreto - Preparo, controle e recebimento: NBR 12655. Rio de Janeiro, 2006.

[6] ASSOCIAÇÃO BRASILEIRA DE NORMAS TÉCNICAS. Concreto - determinação da consistência pelo abatimento do tronco de cone: NM 67, 1998.

[7] AMERICAN SOCIETY FOR TESTING AND MATERIALS. C215-08: Standard test method for fundamental transverse, longitudinal and torsional frequencies of concrete specimens. Philadelphia, 2008.

[8] CONFEA. Conselho Federal de Engenharia e Agronomia A falta de Engenheiros. Disponível em: <http:.//www.confea. org. br/cgi/cgilua.exe/sys/start.htm?infoid=15360\&sid=1206> Acesso em: 08 de dezembro de 2015.

[9] CUNHA, Albino Joaquim Pimenta; et a.. Acidentes Estruturais na Construção Civil. Editora Pini LTDA, Volume I, São Paulo/ SP, 1996.

[10] DIÓGENES, H. J. F.; COSSOLINO, L. C.; PEREIRA, A. H. A.; DEBS, M. K. El; DEBS A. L. H. C. El. Determinação do módulo de elasticidade do concreto a partir da resposta acústica. Revista IBRACON de Estruturas e Materiais, São Paulo, 2011.
[11] DATASUS. Ministério da Saúde. Sistema Único de Saúde. Renda Média Domiciliar per Capita. Disponível em: < http://tabnet.datasus.gov.br/cgi/deftohtm.exe?ibge/censo/cnv/rendabr. def >. Acesso em: 08 de dezembro de 2015.

[12] GOMES NETO, David de Paiva; et al..A situação do controle tecnológico do concreto em Obras da região centro-sul de Sergipe. In: CONGRESSO BRASILEIRO DO CONCRETO, 51, 2009, Curitiba. Anais.

[13] IBGE. Cidades@. Disponível em: < http://cidades.ibge.gov.br/ xtras/perfil.php?lang=\&codmun=240080\&search=rio-grandedo-norte|angicos >. Acesso em: 10 maio. 2014.

[14] MEHTA, P. K.; MONTEIRO, P. J. M. Concreto: estrutura, propriedades e materiais. São Paulo: PINI, 2008.

[15] MATTA, Daniel T.; et al.. Estudo comparativo do desempenho técnico e financeiro entre os concretos preparados na usina e na obra. In: CONGRESSO NACIONAL EM EXCELÊNCIA EM GESTÃO, 10, 2014, Rio de Janeiro. Anais.

[16] MAGALHÃES, Fábio Costa. A problemática dos concretos não conformes e sua influência na confiabilidade de pilares de concreto armado. Universidade Federal do Rio Grande do Sul, Escola de Engenharia, Programa de Pós-Graduação em Engenharia Civil, Porto Alegre/RS, 2014. Tese de Doutorado.

[17] SANTIAGO, Wagner Carvalho. Estudo da (não-) conformidade de concretos produzidos no Brasil e sua influência na confiabilidade estrutural. Escola de Engenharia de São Carlos da Universidade de São Paulo, Programa de Pós-Graduação em Engenharia de Estruturas, São Carlos/SP, 2011. Dissertação de Mestrado.

[18] SEINFRA. Secretária da Infraestrutura do Estado do Ceará. Disponível em: <http://www.seinfra.ce.gov.br/index.php/tabelade-custos-unificada>. Acesso em: 09 de dezembro de 2015. 